\title{
Work Engagement and Employees' Performance: Assessing the Linkage and Leverage in Classified Hospitality Firms in Kenya
}

\author{
Paul Thumbi Njoroge ${ }^{1^{*}} \quad$ Hannah Bula $^{2} \quad$ Rosemarie Wanyoike ${ }^{3}$ \\ 1.PhD Candidate, School of Business, Kenyatta University, Nairobi, Kenya \\ 2.Senior Lecturer, School of Business, Kenyatta University, Nairobi, Kenya \\ 3.Lecturer, School of Business, Kenyatta University, Nairobi, Kenya
}

\begin{abstract}
Work engagement which relates to personal investment of individual physical, emotional and cognitive resources to role performance has continued to gain prominence in human resource practice and theory. Empirical literature reveal that work engagement explains employees' behaviour and outcomes that are consistent with organizational social and psychological contexts. However, there is no consensus in literature on the measures of work engagement that have a direct influence on employees' performance and how firms can create contexts for work engagement to drive performance at employees' level. Therefore, the purpose of this study was to determine the configuration of work engagement elements that influence employees' performance, assess the contextual factors that affect work engagement and ultimately examine how work engagement can be leveraged to enhance employees' performance. Using purposive and stratified random sampling, a sample of 225 respondents was selected from 75 classified hospitality firms in Kenya. Data was collected using a self-administered questionnaire and analyzed using multiple regression analysis. The results showed that work engagement constructs of physical engagement, emotional engagement and cognitive engagement were positively correlated with employees' performance. The study revealed that physical engagement influenced the quality and quantity of employees' output, emotional engagement influenced employees' citizenship behaviour, and cognitive engagement had higher influence on employees' efficiency in performance. The study established that work engagement is connected to employees' motivation factors and is impacted by contextual factors. Organizations should manage the elements of motivation such as compensation and leadership support and job level elements such as decision making, scope of responsibility and supervision in order to create a climate for engaged workers. Work arrangement and job autonomy are crucial in improving employee's devotion and commitment in his role.
\end{abstract}

Keywords: cognitive engagement, emotional engagement, employees' performance, physical engagement, work engagement

DOI: $10.7176 / \mathrm{EJBM} / 13-2-01$

Publication date: January $31^{\text {st }} 2021$

\section{Introduction}

Hospitality firms operate in a labour-intensive sector that relies heavily on human interactions to achieve optimal performance in terms of efficiency and service delivery. To address the customer needs for quality products and service delivery, hospitality firms have to improve performance at employee level (Li \& Zheng, 2014). This assertion is echoed by Isa, Ugheoke and Noor (2016) postulation that success of hospitality firms is largely hinged on employee's performance. Empirical literature indicates that that engagement influence job performance dimensions of task performance and organizational citizenship behavior with engaged employees exhibiting performing tasks with more enthusiasm, vigour, dedication and focus (Rich, LePine, \& Crawford, 2010). Past studies have established that work engagement is positively correlated with task and contextual performance. This linkage is ascertained by engaged workers propensity to be persistent, intense, vigilant and focused in task performance while simultaneously investing energy and behaving in sync with the organizational values and goals. It is argued that engaged employees are cognitively alert, attentive and focused in their behaviour and are emotionally connected to their overall job performance (Christian, Garza \& Slaughter, 2011).

Classified hospitality firms in Kenya have been confronted with enormous market competition by other players in the East African region (KNBS, 2018). The sector's competitiveness is hinged on employee performance as they are instrumental in enhancing customer experience through effective service delivery (Bilgihan \& Nejad, 2015). The threat to the competitiveness of the hospitality sector in Kenya is attributed to low productivity and performance at employee level. According to the National Tourism Blueprint (NTB) 2030, the human resource management practices in the sector are characterized by lack of proper strategies to enhance employee's performance which has ultimately led to the declining performance of the hospitality sector, which currently stands below 70 per cent of the projected performance level.

Empirical studies show that employee's performance plays a significant role in the success of service-oriented firms. In hospitality firms, employee's role is critical because they create and deliver the hospitality products and services (Lacap, 2014). Therefore, attention should be paid to ways in which the organization can enhance the performance of employees. However, hospitality firms in Kenya have focused on performance at organizational 
level and ignored it at employee level (NTB, 2017). Employees' Performance is influenced by organizational antecedents. Past studies have drawn positive relationship between work engagement and employees' performance (Rich, et al, 2010; Christian, et al. 2011; Anitha, 2014)

However, various scholars have adopted various methods to conceptualize and operationalize the construct of employee's performance. Constructs such as turnover intentions, commitment, motivation, engagement and job satisfaction have been included in the wider concept of employee's performance. Some studies have adopted a unidimensional view of employee performance by focusing exclusively on job performance while others have adopted a multi-dimensional approach that incorporates job-specific aspects and non-job specific aspects of performance. This state of literature brings empirical vagueness and compounds the challenge of conceptualizing employees' performance (Luo, Shi, Li, \& Miao, 2008).

On the other hand, empirical evidence reveal inconsistency in the operationalization of the construct of work engagement. To a large extent the construct has been measured using the Utrecht Work Engagement Scale (Schaufeli, et al, 2002). However, as Rich, et al. (2010) argue the measures do not incorporate the three dimensions (physical, emotional and cognitive) underlying the Kahn's (1990) engagement theory. In order to address these gaps, this study adapted Rich, et al. (2010) model of work engagement and employees' performance was studied from the multidimensional approach in line with Borman \& Motowidlo (1993) model.

The general objective of this study was to examine the effect of work engagement on employees' performance in classified hospitality firms in Kenya.

The specific objectives of this study were:

i) To establish the effect of physical engagement on employees' performance in classified hospitality firms in Kenya

ii) To determine the effect of emotional engagement on employees' performance in classified hospitality firms in Kenya

iii) To assess the effect of cognitive engagement on employees' performance in classified hospitality firms in Kenya

The research hypotheses for this study were stated in the null hypothesis as follows:

i. Ho $\mathrm{Ho}_{1}$ Physical engagement has no significant effect on employees' performance in classified hospitality firms in Kenya

ii. $\mathrm{Ho}_{2}$ : Emotional engagement has no significant effect on employees' performance in classified hospitality firms in Kenya

iii. $\mathrm{Ho}_{3}$ : Cognitive engagement has no significant effect on employees' performance in classified hospitality firms in Kenya

The study adds to the body of knowledge by empirically examining the linkage between work engagement and employees' performance using broader conceptualization and configuration of the two variables based on engagement theory and task and contextual model of performance. Further, the findings provide insights on how organizations can harness work environment that creates, supports and sustains optimal level of work engagement and employees' performance.

\section{Literature Review}

\subsection{Theoretical Review}

\subsubsection{Task and Contextual Performance Model}

The concept of employee's performance can be broadly described as an employee's output from task performance and behaviour linked to achievement of organizational goals (Campbell, 1990). The scientific management perspective view of employee's performance was largely concerned with quantity output of the worker. With advent of human relations school of thought, the view of employees' performance was enhanced to include both quantity and quality dimensions. Therefore, employees' performance was measured in terms of efficiency (rate of output), efficacy (goal accomplishment) and quality (standards of performance) (Dhammika, 2013).

Although the dimensions of employee's performance described by Campbell (1990) including job proficiency, communication, discretionally effort, discipline, team work, and leadership continue to elicit interest, the concept of employees' performance has not been operationalized uniformly in literature. Task and contextual performance model by Borman and Motowidlo (1993) has been embraced by some scholars The model view task performance as a description of employee's effectiveness in executing technical activities while contextual performance refers to employee's undertaking of activities that relate to social, cultural and psychological contexts or dimensions of the organization. The contextual performance dimensions comprise enthusiasm, extra effort, volunteering, assisting and cooperating with coworkers, adhering to rules and procedures and participating in corporate affairs (Borman \& Motowidlo, 1993).

This model has gained traction in research with the conceptualization of employee performance gaining numerous empirical support, albeit with additional constructs such as job dedication, which entail self-discipline and following organizational rules and regulations, and interpersonal facilitation, involving cooperating and 
helping co-workers (Luo, et al. 2008). Dhammika (2013) tested the validity of the task and contextual model of performance and the results showed that measures such as task execution, job proficiency, efficiency, assisting coworkers, cooperation, and team work were valid measures of employee's performance. This study adopted task and contextual model to measure employee's performance. The indicators of employees' performance, therefore, included service delivery, efficiency, team work, and citizenship behaviour.

\subsubsection{Kahn's Engagement Theory}

The engagement theory proposes that work engagement entails the simultaneous employment of individual's physical, emotional and cognitive resources in assigned role (Kahn, 1990). Rich, LePine, and Crawford (2010) posit that physical resources relate to energy and vigour, emotional resources relates to dedication and attachment, and cognitive resources relate to job focus and absorption. This engagement is reflected in individual workers investment of energy and vigour, dedication and attachment and focus and absorption in their work. However, this involvement should be simultaneous rather than fragmented (Kahn, 1992). This conceptualization suggests a linkage between engagement and job performance (Rich, et al, 2010

It is argued that work engagement influence employee's performance because the more an individual puts more energy, is focused and dedicated the more and better the outcomes of their labour (Hillman, Nicholson, \& Shropshire, 2008). Employees who are absorbed and dedicated exhibit more enthusiasm, are more alert and attentive, and enjoy their work which leads to enhanced performance. Work engagement provides a mechanism that explains the relationship between individual characteristics and organizational factors related to job performance and behaviour. Empirical studies have drawn a direct influence between work engagement and employee's performance (Christian, et al. 2011)

Engagement theory proposes that the psychological experience that drive work related behaviour are influenced by individual and organizational factors (Kahn (1990). The construct of work engagement is understood to explain employee behaviour and performance (Newman \& Harrison, 2008). Empirical literature suggests that work engagement entails motivational effect that lead to higher levels of job performance. Studies reveal that work engagement leads to employee's behaviours and outcomes that are consistent with organizational social and psychological contexts (Christian, et al., 2011).

The measures of work engagement as espoused and advanced by Rich et al. (2010) and Christian, et al. (2011) were adapted for this study. Therefore, the indicators of work engagement for this study were willingness to dedicate physical, emotional and cognitive resources to the job (task and contextual) performance. The physical construct entailed energy, resilience and vigour, emotional involved the attachment or dedication to one's work performance, and cognitive involved job focus, absorption and vigilance (Christian, et al., 2011).

\subsection{Empirical Review}

Empirical evidence validates the positive influence of work engagement on performance outcomes at both organizational and employee level. Rich, et al. (2010) investigated the antecedents and effects of job engagement on job engagement. The study sampled 245 respondents in USA and analyzed data using inferential statistics, correlation analysis, structural modeling and factor analysis. The results indicated that engagement influence job performance dimensions of task performance and organizational citizenship behavior. In addition, the findings revealed that an engaged employee exhibit improved performance outcomes since they performed tasks with more enthusiasm, vigour, dedication and focus.

Christian, et al. (2011) sought to examine work engagement and its relationship with task and contextual elements of employee performance. The study adopted meta-analytic path modelling to determine the relationship between the variables. The study established that work engagement was positively correlated with task and contextual performance. This linkage is ascertained by engaged workers propensity to be persistent, intense, vigilant and focused in task performance while simultaneously investing energy and behaving in sync with the organizational values and goals. The study, further, revealed that engaged employee are cognitively alert, attentive and focused in their behaviour and are emotionally connected to their overall job performance.

A study by Anitha (2014) sought to establish the factors affecting employee engagement and employee performance. The study adopted causal study method in which a sample of 700 middle and lower managers from SMEs in India was selected using simple random sampling. Data was analyzed using regression and structural equation modelling. The results indicated that engagement had a positive influence on employee's performance and had a mediation role between its antecedents and effects. The study, further, drew association between work engagement and employee's job satisfaction and citizenship behaviour, intentions to quit, burnout level and employee performance.

Banihani and Syed (2017) conducted a study on gendered work engagement in telecommunication companies in Jordan. The study sampled thirty six employees from three firms. As an entirely qualitative research, the study used content analysis. The study revealed that contextual aspects of work environment influenced performance. Work engagement is associated with motivational influence on employee's performance as it creates a climate of trust, enthusiasm and warmth. Further, the results showed that work engagement characterized by vigour, 
dedication and absorption which has positive effects on employee's performance.

Kim and Park (2017) investigated the relationships between work engagement and employee's behavior. A sample of 400 employees from public-sector organizations in Korea were surveyed. Data was analyzed using structural equation modeling. The findings showed that work engagement impacted employee's performance. In addition work engagement influenced knowledge sharing, procedural justice and employee's innovative behaviour. Ajayi, et al., 2017 examined the relationship between the organizational context and employee engagement in Nigeria. Using Cross sectional design, a sample of 200 SMEs was selected for the study. The findings show that employee engagement increases their performance and consequently enhances organizational potential for growth and survival.

\subsection{Conceptual Framework}

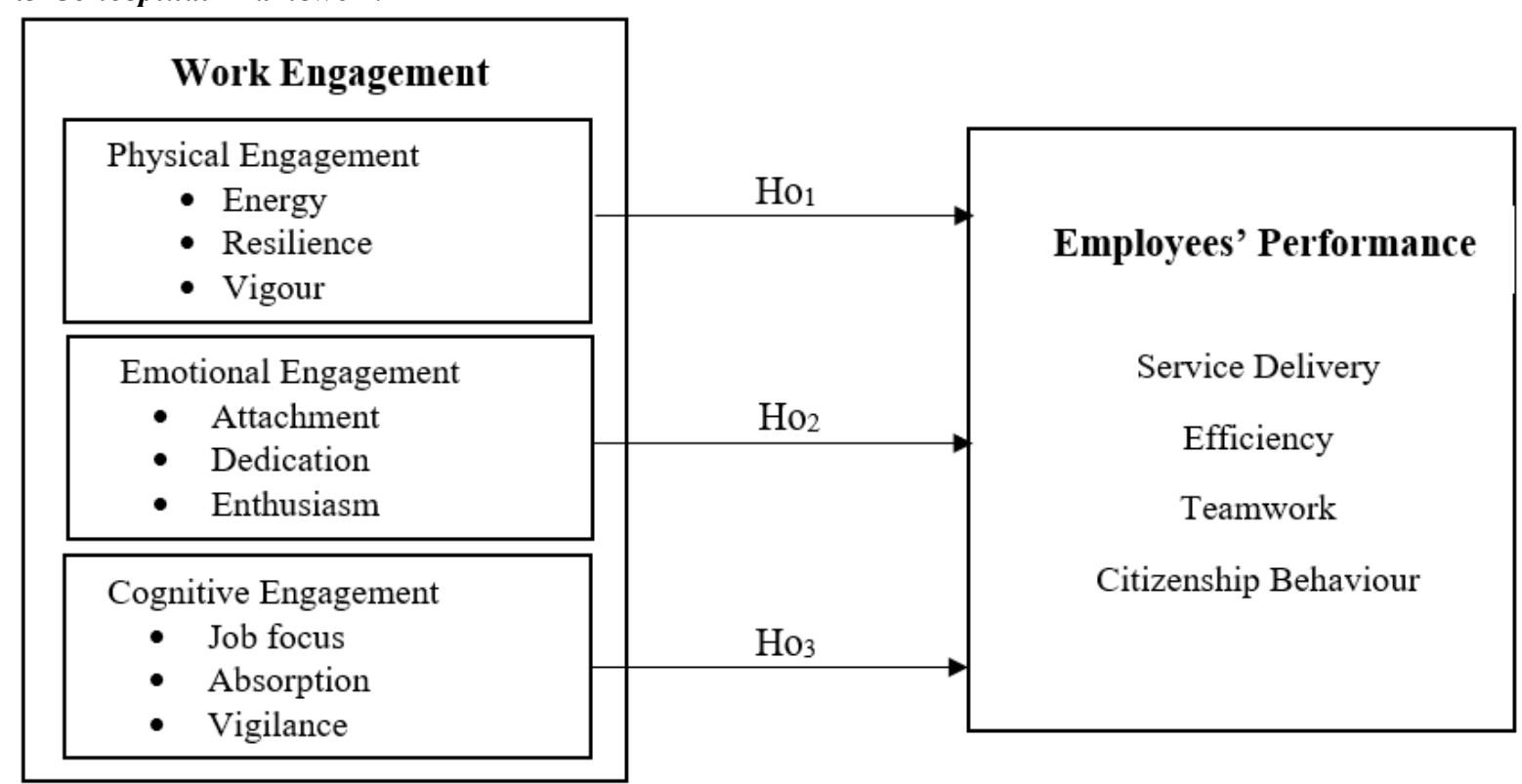

Figure 2.1: Conceptual Framework

Source: Njoroge, Bula and Wanyoike (2020)

\section{Research Methodology \\ 3.1 Research Design}

This study adopted a positivist research philosophy to examine the effect of work engagement on employees' performance in classified hospitality firms in Kenya. The choice was also supported by Creswell (2009) recommendation that positivist research philosophy is appropriate for explaining relationships between variables with cause and effect attribute. According to Easterby-Smith, Thorpe and Jackson (2008), positivism is ideal for research that progresses from problem statement, setting of objectives and hypothesis formulation and testing, operationalization and measurement of study variables, and generalization of findings are made through statistical probability. Descriptive and explanatory research designs were adopted for the study. The designs are more reliable and suitable in determining the relationships between variables, establishing models of these relationships and testing hypotheses (Saunders, et al., 2012). Cross-sectional survey method was used as data was collected and the relationship between variables measured at a specified time.

\subsection{Target Population and Sampling}

A target population of 75 firms representing $38 \%$ was selected using purposive sampling method. The firms comprised 15 five star, 35 four star and 25 three star firms located in Nairobi and South-Rift Valley regions. The unit of analysis was the classified hospitality firms while the unit of observation was the functional departments in each firm. The functional departments that were considered for observation were human resources, food and beverage, and accommodation and conferencing. These departments were considered because they had relevant information for the study. Using stratified random sampling, a proportionate number of respondents were selected from each category or strata and three functional departments. As a result, the sample size comprised 225 respondents.

\subsection{Data Collection Instrument and Procedure}

Data was collected using a questionnaire. A questionnaire provides a consistent and efficient way of collecting 
information related to individual attitudes, perceptions, and behavioural characteristics (Creswell, 2009). The use of a questionnaire was appropriate for this study as it is sufficient to collect both quantitative and qualitative data for descriptive research (Saunders, et al. 2012). In the development of the questionnaire, Creswell and Plano-Clark (2011) procedure was followed which entailed: determining relevant study constructs and measures; generation of questionnaire items and relevant questions; ensuring that items scales were validated by previous studies; determining the scales of measurement of the items; pre-testing to validate the instrument; and evaluating the items for reliability. Based on this systematic approach, a semi-structured questionnaire was developed comprising both closed-ended and open-ended questions. The closed ended questions were structured using a five-point Likert scale format.

A cross-sectional design was adopted for data collection in order to accurately capture the objectives of the study, provide valid measure of variables and get time-specific information from respondents. The questionnaire was administered to the respondents who comprised a human resource manager, food and beverage manager, and accommodation and conferencing manager from each selected firm. The questionnaire was delivered by hand to each respondent and collected later by the researcher. The pilot study was conducted and after revision of the questionnaire, data was collected over a period of one month.

\subsection{Measurement of Variables}

The measures of study variables were adapted from models used in past studies. Employees' performance, which is the dependent variable, was operationalized based on the indicators advanced in the task and contextual model. The measures adopted to indicate task and contextual performance for this study were service delivery, efficiency, teamwork, citizenship behavior espoused by Borman and Motowidlo (1993). Service delivery measured the quality of service in meeting customer needs, timeliness and service standards, efficiency involved performing roles competently without mistakes and solving problems related to tasks, team work entailed employee's contribution to team activities, commitment to team goals and leading team efforts, and citizenship behaviour which was measured in terms of assisting co-workers, following organizational rule and involvement in corporate affairs.

On the other hand, work engagement, the independent variable, was operationalized using measures of work engagement as espoused and advanced by Rich et al. (2010) and Christian, et al. (2011) which include physical resources, emotional resources and cognitive resources. The physical engagement indicators were energy, resilience and vigour; emotional engagement indicators included attachment, dedication and enthusiasm; and cognitive engagement was indicated by job focus, absorption and vigilance.

\subsection{Validity and Reliability}

Tests for validity of research instrument was conducted to ensure that it measures what it is purported to measure using content validity assessment and criterion-related assessment (Cooper \& Schindler, 2006). To ascertain validity, the questionnaire was reviewed by specialists in academia and practice. In addition, the researcher adapted measures that have been validated in previous studies. To test the reliability of the quantitative measures, Cronbach's Alpha Coefficient statistical method was used since it is considered suitable for measuring internal consistency when multiple Likert questions have been used (Saunders, et al. 2012). Internal consistency of questionnaire items was considered adequate if they had a Cronbach's alpha coefficient value of 0.7 or higher (Hair, et al. 2006).

\subsection{Data Analysis}

The collected data was analyzed and interpreted using descriptive and inferential statistics. The descriptive statistics that was used are mean and standard deviation and inferential statistics done included multiple regression and correlation analyses to measure causal relationship between and among study constructs and test hypotheses. In particular, regression analysis was used to test hypotheses to establish if there was a statistically significant relationship between work engagement constructs and employees' performance and examine how changes in these constructs influence changes on as well as predict employees' performance. Pearson correlation was used to determine the association between the explanatory variables (physical engagement, emotional engagement and cognitive engagement) and the dependent variable (employees' performance). The strength and direction of linear relationships between pairs of study variables were measured. 


\subsection{Hypotheses Testing}

Table 3.1: Hypotheses Testing

\begin{tabular}{|c|c|c|c|}
\hline $\begin{array}{l}\text { Hypothesis } \\
\text { (Ho) }\end{array}$ & $\begin{array}{l}\text { Hypothesis } \\
\text { Test }\end{array}$ & Statistical Model & Interpretation \\
\hline $\begin{array}{l}\text { Ho }_{1:} \text { Physical } \\
\text { engagement } \\
\text { has no effect } \\
\text { on employees } \\
\text { performance } \\
\text { in classified } \\
\text { hospitality } \\
\text { firms in Kenya }\end{array}$ & $\begin{array}{l}X_{0}: \beta=0 \\
X_{0}: \beta \neq 0 \\
\text { Reject } H_{0} \text { if } \\
p<0.05, \\
\text { If not fail to } \\
\text { reject the } H_{0}\end{array}$ & $\begin{array}{ll}\mathrm{Y}=\beta_{10}+\beta_{11} \mathrm{X}_{11}+\beta_{12} \mathrm{X}_{12}+\beta_{13} \mathrm{X}_{13}+\varepsilon \\
\text { Where: } \\
\mathrm{Y} & =\text { Employees Performance } \\
\mathrm{X}_{11} & =\text { Physical engagement } \\
\mathrm{X}_{12} & =\text { Emotional engagement } \\
\mathrm{X}_{13} & =\text { Cognitive engagement }\end{array}$ & $\begin{array}{l}\text { Physical engagement, } \\
\mathrm{X}_{11} \text {, has significant effect } \\
\text { on employees } \\
\text { performance, } \mathrm{Y}_{1} \text {, if the } \\
\text { regressed } \beta_{11} \text { coefficient } \\
\text { for } \beta_{11} \mathrm{X}_{11} \text { product term is } \\
\text { statistically significant, } \mathrm{p} \\
<0.05\end{array}$ \\
\hline $\begin{array}{l}\mathrm{Ho}_{2} \text { : } \\
\text { Emotional } \\
\text { engagement } \\
\text { has no effect } \\
\text { on employees } \\
\text { performance } \\
\text { in classified } \\
\text { hospitality } \\
\text { firms in Kenya }\end{array}$ & $\begin{array}{l}\mathrm{X}_{0}: \beta=0 \\
\mathrm{X}_{0}: \beta \neq 0 \\
\text { Reject } \mathrm{H}_{0} \text { if } \\
\mathrm{p}<0.05, \\
\text { If not fail to } \\
\text { reject the } \mathrm{H}_{0}\end{array}$ & $\begin{array}{ll}\varepsilon & =\text { Error term } \\
\beta_{10} & =\text { Intercept } \\
\beta_{11-}-\beta_{13} & =\text { Slope coefficients }\end{array}$ & $\begin{array}{l}\text { Emotional engagement, } \\
\mathrm{X}_{12} \text {, has significant effect } \\
\text { on employee's } \\
\text { performance, } \mathrm{Y}_{1} \text {, if the } \\
\text { regressed } \beta_{12} \text { coefficient } \\
\text { for } \beta_{12} \mathrm{X}_{12} \text { product term is } \\
\text { statistically significant, } \mathrm{p} \\
<0.05\end{array}$ \\
\hline $\begin{array}{l}\text { Ho3: Cognitive } \\
\text { engagement } \\
\text { has no effect } \\
\text { on employees } \\
\text { performance } \\
\text { in classified } \\
\text { hospitality } \\
\text { firms in Kenya }\end{array}$ & $\begin{array}{l}\mathrm{X}_{0}: \beta=0 \\
\mathrm{X}_{0}: \beta \neq 0 \\
\text { Reject } \mathrm{H}_{0} \text { if } \\
\mathrm{p}<0.05, \\
\text { If not fail to } \\
\text { reject the } \mathrm{H}_{0}\end{array}$ & & $\begin{array}{l}\text { Cognitive engagement, } \\
\mathrm{X}_{13} \text {, has significant effect } \\
\text { on employee's } \\
\text { performance, } Y_{1} \text {, if the } \\
\text { regressed } \beta_{13} \text { coefficient } \\
\text { for } \beta_{13} \mathrm{X}_{13} \text { product term is } \\
\text { statistically significant, } \mathrm{p} \\
<0.05\end{array}$ \\
\hline
\end{tabular}

Source: Njoroge, Bula and Wanyoike (2020)

\section{Research Findings and Discussion}

\subsection{Reliability of Research Instrument}

The results of reliability test presented in table 4.1 reveal that the questionnaire had internal consistency with all items having a coefficient value greater than 0.7 as recommended by Hair, et al. (2012).

Table 4.1: Reliability Test Results

\begin{tabular}{llcc}
\hline Variables & Measures & No. of Items & Cronbach's Alpha \\
\hline Work Engagement & Physical engagement & 3 & 0.921 \\
(Independent Variable) & Emotional engagement & 3 & 0.870 \\
& Cognitive engagement & 3 & 0.853 \\
\hline Employees Performance & Service delivery & 3 & 0.913 \\
(Dependent Variable) & Efficiency & 3 & 0.877 \\
& Team Work & 3 & 0.944 \\
& Citizenship Behaviour & 3 & 0.928 \\
\hline
\end{tabular}

Source: Njoroge, Bula and Wanyoike (2020)

\subsection{Response Rate}

Two hundred and twenty five (225) questionnaires were administered to respondents who comprised human resource managers, food and beverage managers and accommodation and conferencing managers. One hundred and sixty two (162) of the completed questionnaires respondents were considered valid for the study which is equivalent to 72 per cent response rate.

\subsection{Demographic Characteristics of Respondents}

The study sought to establish the demographic characteristics of the respondents in terms of gender, age, level of education, length of service and department of operation. The results of demographic characteristics revealed that in classified hospitality firms studied, there is an almost even distribution of male and female in management with male respondents accounting for $52.5 \%$ and female $47.5 \%$ respectively. Majority of the respondents fall between the age of 20 years to 49 years, with highest category being aged between $30-39$ years which is $38.9 \%$ and the 
least category is aged between $50-59$ years which is 5.6\%. A big proportion of the respondents have either a diploma or a Bachelor's degree representing 32.7\% and $46.9 \%$ respectively. In terms of length of service, $44.4 \%$ have worked in the organization for less than 4 years, $24.7 \%$ for a period between 5 and 9 years. Only $14.2 \%$ have worked for over 15 years. The highest number of respondents, that is, $38.9 \%$ work in human resource department, $33.3 \%$ in food and beverage department and $27.3 \%$ in accommodation and conferencing.

\subsection{Level of Work Engagement}

A nine-item scale was used to examine the level of work engagement in the firms. Using a five-point Likert scale from 1 "strongly disagree" to 5 "strongly agree," respondents were required to indicate their extent of agreement with item statements. The results are presented in table 4.2 below. Table 4.2: Level of Work Engagement

\begin{tabular}{llccc}
\hline Variable & Constructs & N & Mean & Std. Dev \\
\hline Physical Engagement & Vigour & 162 & 4.125 & 0.677 \\
& Resilience & 162 & 4.068 & 0.762 \\
& Energy & 162 & 3.942 & 0.906 \\
\hline \multirow{2}{*}{ Emotional Engagement } & Enthusiasm & 162 & 3.764 & 0.888 \\
& Attachment & 162 & 3.539 & 1.075 \\
& Dedication & 162 & 3.758 & 0.971 \\
\hline Cognitive Engagement & Job Focus & 162 & 4.299 & 0.581 \\
& Vigilance & 162 & 3.972 & 0.857 \\
& Absorption & 162 & 3.715 & 1.004 \\
\hline
\end{tabular}

Likert scale (1 -5): $\leq 2.49=$ Low $\geq 2.50 \leq 3.49=$ Moderate; $\geq 3.50=$ High.

Source: Njoroge, Bula and Wanyoike (2020)

From the results presented in table 4.2, it is evident that there is a high level of work engagement in the classified hospitality firms with most items recording a mean above 3.500. On items measuring physical engagement, the results indicate that employees who work with intensity record better performance (Mean 4.125, Std dev 0.677), those that strive to excel in their work have higher quality output (Mean 4.068, Std dev 0.762) and those that who devote a lot of energy in their work have higher quantity of output (Mean 3.942, Std dev 0.906). These results are consistent with empirical studies (Anitha, 2014) which opine that the level of employees' behaviour and output is influenced by work engagement.

In terms of emotional engagement, the findings reveal that an employee's enthusiasm, passion attitude influence their work. It is evident that employees who are enthusiastic about their work are more willing to take up additional responsibilities (Mean 3.764, Std dev 0.888), those who are proud of their work are more loyal to the organization (Mean 3.539,Std dev 1.075) and those who take their work as a positive challenge are able to solve work related problems (Mean 3.758, Std dev 0.971). These results echo Rich, et al. (2010) view that work engagement influences job performance dimensions of task performance and citizenship behaviour.

Cognitive engagement measures including focus, attention and absorption recorded high means in terms of their influence on employees' behaviour. The results show that employees who are focused often meet their performance standards (Mean 4.299, Std dev 0.581), those who pay attention to their work make fewer mistakes (Mean 3.972, Std dev 0,857) and those who are absorbed in their work have lower intentions to leave the organization (Mean 3.715, Std dev 1.004). These findings are consistent with Christian, et al. (2011) argument that engaged workers have more propensity to be persistent, intense, vigilant and focused in their performance of tasks and are more likely to be aligned to organizational values and goals.

\subsection{Influence of Work Engagement Factors on Employees' Performance Indicators}

The study sought to establish the extent to which physical engagement, emotional engagement and cognitive engagement influence employees' performance indicators of service delivery, efficiency, teamwork and citizenship behaviour. The findings showed that physical engagement, in terms of vigour, effort and energy exerted in task performance, has a lot of influence on employees' performance indicators, service delivery, efficiency, team work and citizenship behaviour. The highest level of influence is on service delivery with $84 \%$ of the respondents rating the level as either high or very high. Influence on efficiency is considered at $78 \%(43 \% \mathrm{high}$ and 35\% very high). Physical engagement also has influence on team work (48\% high and $31 \%$ very high influence) and citizenship behaviour (32\% high and $27 \%$ very high). It is notable that work has least influence on citizenship behaviour a total of $41 \%$ of respondents considering the influence as either, moderate, low or very low.

The results revealed that emotional engagement, in terms of dedication, enthusiasm and passion, influence employees' performance aspects including service delivery, efficiency, teamwork and citizenship behaviour. The highest level of influence of emotional engagement is on efficiency ( $41 \%$ high and $45 \%$ very high) followed by service delivery (54\% high and 23\% very high), teamwork (41\% high and $33 \%$ very high) and citizenship behaviour ( $36 \%$ high and 19\% very high). It was evident from the findings that cognitive engagement, that is focus 
and absorption, has influence on employees' performance. In particular, cognitive engagement has more influence on service delivery which has a high level influence of $44 \%$ and very high level $26 \%$. On efficiency, the influence is relatively high $(36 \%$ high and $27 \%$ very high). The influence on team work and citizenship behaviour is moderate, $33 \%$ and $36 \%$ high respectively.

These results imply that for there to be improved service delivery and efficiency at employees' level of performance, the organization must improve the cognitive engagement elements, focus and absorption. Although the influence on teamwork and citizenship is only moderate, it remains significant. These findings are consistent with empirical literature which draw a relation between work engagement and employees' performance (Rich, et al, 2010; Anitha, 2014; Banihani \& Syed, 2017).

\subsection{Correlation between Work Engagement and Employees' Performance}

A correlation analysis to determine the relationship between work engagement and employees' performance was conducted. The test aimed to ascertain whether the relationship was statistically significant at $95 \%$ level of confidence using a two tailed test. The results are presented in table 4.3.

Table 4.3: Correlation between Work Engagement and Employees' Performance

\begin{tabular}{llllc}
\hline Dimension & & $\begin{array}{l}\text { Physical } \\
\text { Engagement }\end{array}$ & $\begin{array}{l}\text { Emotional } \\
\text { Engagement }\end{array}$ & $\begin{array}{c}\text { Cognitive } \\
\text { Engagement }\end{array}$ \\
\hline Employees' & Pearson Correlation & $.788^{* *}$ & $.754^{* *}$ & $.712^{* *}$ \\
Performance & Sig. (2-tailed) & 0.000 & 0.001 & 0.003 \\
& $\mathrm{~N}$ & 162 & 162 & 162 \\
\hline
\end{tabular}

**Correlation is significant at the 0.01 level (2-tailed)

Source: Njoroge, Bula and Wanyoike (2020)

The results shown in table 4.3 reveal that there is a strong positive correlation between work engagement and employees' performance. Correlation between physical engagement and employees performance is statistically significant, $\mathrm{r}=0.788^{* *}, \mathrm{p}(0.000)<005$, emotional engagement and employees' performance is statistically significant, $\mathrm{r}=0.754^{* *}, \mathrm{p}(0.001)<0.05$, and cognitive engagement and employees' performance is also statistically significant, $r=0.712 * *, p(0.003)<0.05$. These results are in consonance with empirical literature that has found correlation between work engagement and employees' performance (Christian, et al. 2011; Banihani \& Syed (2017).

\subsection{Regression Analysis}

In order to test hypotheses, linear regression analysis was performed. The regression analysis used to examine how changes in the independent variables (Physical engagement, emotional engagement and cognitive engagement) influenced changes in the dependent variable (employees' performance). The results are presented in table 4.4. Table 4.4: Model Summary

\begin{tabular}{lllcc}
\hline Model & $\mathrm{R}$ & R Square & Adjusted R Square & Std. Error of the estimate \\
\hline 1 & .774 & .599 & .562 & .684 \\
\hline
\end{tabular}

Predictors: (Constant), physical engagement, emotional engagement, cognitive engagement

Source: Njoroge, Bula and Wanyoike (2020)

The results presented in table 4.4 show a significant proportion of variance in performance $\left(\mathrm{R}^{2}=0.599\right)$. The results indicate that the independent variables collectively explain $59.9 \%$ of the variation in employees' performance. This implies a significant influence of work engagement on employees' performance in classified hospitality firms.

Table 4.5: ANOVA

\begin{tabular}{llccccc}
\hline & Model & Sum of squares & df & Mean square & F & Sig. \\
\hline 1 & Regression & 89.63 & 3 & 29.88 & 63.57 & .000 \\
& Residual & 74.26 & 158 & 0.47 & & \\
Total & 163.89 & 161 & & & \\
\hline
\end{tabular}

a. Predictors: (Constant), physical engagement, emotional engagement, cognitive engagement

b. Dependent variable: employees' performance

Source: Njoroge, Bula and Wanyoike (2020)

The study tested the overall significance of the model using ANOVA (F) test at $95 \%$ confidence level. The results indicate that the regression model predicts the dependent variable significantly. The sig. $p<0.00$ is less than 0.05 which means that the regression model statistically significantly predicts the outcome variable. That is, the independent variables physical engagement, emotional engagement and cognitive engagement can be used to reliably predict employees' performance (dependent variable). The results in table 4.5 implies that the relationship between work engagement and employees' performance is statistically significant at 0.05 significance level. 


\begin{tabular}{|c|c|c|c|c|c|}
\hline \multirow[b]{2}{*}{ Model } & \multicolumn{2}{|c|}{ Unstandardized coefficients } & \multirow{2}{*}{$\begin{array}{c}\text { Standardized coefficients } \\
\text { Beta }\end{array}$} & \multirow{3}{*}{$\frac{\mathrm{t}}{2.993}$} & \multirow{3}{*}{$\frac{\text { Sig. }}{.000}$} \\
\hline & $\mathrm{B}$ & Std. Error & & & \\
\hline $\begin{array}{ll}1 & \text { (Constant) }\end{array}$ & 1.652 & .552 & & & \\
\hline Physical engagement & .469 & .356 & .177 & 1.318 & .000 \\
\hline Emotional engagement & .586 & .361 & .269 & 1.622 & .000 \\
\hline Cognitive engagement & .814 & .549 & .181 & 1.483 & .004 \\
\hline
\end{tabular}

a. Dependent Variable: employees' performance

Source: Njoroge, Bula and Wanyoike (2020)

From the statistical model, $Y=\beta_{10}+\beta_{11} X_{11}+\beta_{12} X_{12}+\beta_{13} X_{13}+\varepsilon$, and based on regression analysis results shown in table 4.7, the regression model is stated as $\mathrm{Y}=1.652+0.469 \mathrm{X}_{11}+0.586 \mathrm{X}_{12}+0.814 \mathrm{X}_{13}+\varepsilon$

The results of multiple regression analysis presented on table 4.6 were used to test research hypotheses and draw conclusions.

$\mathrm{H}_{01}$ : Physical engagement has no significant effect on employees' performance in classified hospitality firms in Kenya

As indicated in table 4.7, the null hypothesis was rejected since physical engagement significantly predicted employees' performance: $\beta=0.469, p(0.000)<0.05$ at $95 \%$ confidence level. This finding imply that physical engagement has significant effect on employees' performance.

$\mathrm{H}_{02}$ : Emotional engagement has no significant effect on employees' performance in classified hospitality firms in Kenya

The null hypothesis was rejected since emotional engagement significantly predicted employees' performance: $\beta$ $=0.586, p(0.000)<0.05$ at $95 \%$ confidence level. This results reveal that emotional engagement has significant effect on employees' performance.

$\mathrm{H}_{03}$ : Cognitive engagement has no significant effect on employees' performance in classified hospitality firms in Kenya

The null hypothesis was rejected since cognitive engagement significantly predicted employees' performance $\beta=0.814, p(0.004)<0.05$ at $95 \%$ confidence level. This findings imply that cognitive engagement has a significant effect on employees' performance. The results of the multiple regressional analysis show that organizational learning variables of physical engagement are predictors of employees' performance. These finding are consistent with past studies that have established drawn similar conclusion (Anitha, 2014 ; Kim \& Park, 2017).

\subsection{Organizational Factors Impacting Work Engagement}

The study sought to establish the contextual factors in the organization that had significant impact on work engagement and consequently on employees' performance. The results indicate that work engagement is mainly influenced by motivation $39 \%$, job satisfaction $35 \%$, compensation $33 \%$, job autonomy $32 \%$, learning $31 \%$ and leadership support $31 \%$. It is also apparent that communication, welfare programs, decision making and level of supervision are critical factors that impact the level of work engagement. These findings imply that organizations should improve organizational climate or contexts characterized by these factors in order to create positive outcomes in work engagement and employees' performance.

\section{Conclusions}

The findings provide evidence that work engagement influence employees' performance, in which case employees who are physically, emotionally and cognitively engaged have higher positive outcomes. Work engagement a strong statistically significant positive correlation with employees' performance. In addition. Further, the results reveal that employees who put more effort in their work, are more dedicated and focused, are more efficient and are more likely to achieve their performance targets. In addition, they make fewer mistakes, have less disciplinary issues, are more willing to take extra duties and responsibilities, are able to solve problems related to their jobs, and have higher chances for promotion. These findings are consistent with empirical literature (Christian, et al., 2011, Anitha, 2014; Park, et al., 2014; Lin \& Lee, 2017).

Work engagement is connected to employees' motivation, morale and job satisfaction. Organizations should manage the elements of motivation such as compensation and leadership support and job level elements such as decision making, scope of responsibility and supervision in order to create a climate for engaged workers. Work arrangement and job autonomy are crucial in improving an employee's devotion and commitment in his role. Employees want to have some level of control of their jobs and are demoralized by over-supervision and micromanagement. Workers are more likely to put more effort, dedicate more time and remain focused in activities for which they have some level of control and accountability. This is consistent with past studies that have found similar results (Kim \& Park, 2017). 


\section{Recommendations \\ 6.1 Practical Implications}

It is the desire of every organization to have employees who work with vigour and energy, who are devoted and attached to their work, and have job focus and absorption. Such a high level of engagement is positively correlated with high level of positive performance outcomes. However, to achieve such a level of engagement, it is incumbent upon the organization to create a climate that creates, supports and sustains such optimal level of work engagement. Since work engagement is connected to employees' motivation, morale and job satisfaction, the factors that drive it must have motivational influence. Such elements include compensation, leadership support, participative decision making, job autonomy and capacity development. A learning environment provides a conducive environment for work engagement. Organizations should allow employees to have more control over their jobs as workers are more likely to put more effort, dedicate more time and remain focused in activities for which they have some level of control and accountability.

\subsection{Suggestions for Future Research}

The respondents of this study were managers in the human resource, food and beverage and conferencing and accommodation sections of the firm. The respondents were ideal for this study to the extent that they had the relevant information relating to study variables. However, depending on the indicators of and measures used for work engagement and employees' performance, shopfloor employees could provide vital information. Therefore, a future could use multi-level sample categories, management and shopfloor level employees. The management level respondents could respond to firm level questions and shopfloor could be targeted with general employees' questions using a questionnaire.

\section{References}

Ajayi, O. M., Odusanya, K. \& Morton, S. (2017). Stimulating employee ambidexterity and employee engagement in SMEs. Management Decision, 55 (4): 662-680

Anitha, J. (2014). Determinants of employee engagement and their impact on employee performance. International Journal of Productivity and Performance Management, 63(3): 308-323.

Appelbaum, E., Bailey, T., Berg, P., \& Kalleberg, A.L. (2000), Manufacturing Advantage: Why High-performance Work Systems Pay-off, London: Cornell University Press.

Banihani, M., Lewis, P. \& Syed, J. (2013). Is work engagement gendered? Gender in Management: An International Journal, 28(7), 400-423.

Borman, W. C., \& Motowidlo, S. J. (1993). Expanding the criterion domain to include elements of contextual performance. In N. Schmitt, \& W. C. Borman, Personnel Selection in Organizations (71-98). San Francisco: Jossey-Bass

Campbell, J. P. (1990). Modeling the performance prediction problem in industrial and organizational psychology. In M. D. Dunnetee, \& L. M. Hough, Handbook of industrial and organizational psychology (pp. 687-732). Palo Alto: CA: Consulting Psychologists Press

Christian, M.S., Garza, A.S. \& Slaughter, J.E (2011). Work Engagement: A Quantitative Review and Test of its Relations with Task and Contextual Performance. Personnel Psychology, 64: 89-136.

Conway, J. M. (1996). Distinguishing Contextual Performance from Task Performance for Managerial Job. Journal of Applied Psychology, 84, 139-162.

Cooper, D.R. \& Schindler, P.S. (2013). Business Research Methods. $12^{\text {th }}$ Edition, McGraw-Hill Higher Education

Creswell, J. W. (2009). Research Design: Qualitative and Mixed Methods Approaches. SAGE: London, UK.

Datta, D.K., Guthrie, J.P., \& Wright, P.M. (2005). Human Resource Management and Labour Productivity: Does Industry Matter? Academy of Management Journal, 48, 135-145.

Dhammika, K. (2013). Measuring Employees' Performance in the Public Sector in Sri Lanka: Testing of Two Models. Kelaniya Journal of Human Resource Management, 8 (1): 1-21

Hair. J. F. Jr., RE. Anderson, R.L., Tatham \& W.C. Black. (2012). Multivariate Data Analysis with

Kahn, W. A. (1990). Psychological conditions of personal engagement and disengagement at work. Academy of Management Journal, 33: 692-724.

Kahn, W. A. (1992). To be fully there: Psychological presence at work. Human Relations, 45: 321-349.

Lepak, D.P., Liao, H., Chung, Y., \& Harden, E.E. (2006), 'A Conceptual Review of Human Resource Management Systems in Strategic Human Resource Management Research,' Research in Personnel and Human Resource Management, 25, 217-271.

Li, X. \& Zheng, Y. (2014). The Influential Factors of Employees' Innovative Behavior and the Management Advices. Journal of Service Science and Management, 7, 446-450

Lin, H \& Lee, Y. (2017). A Study of the Influence of Organizational Learning on Employees' Innovative Behavior and Work Engagement by a Cross-Level Examination. Journal of Mathematics Science and Technology Education, 13(7); 3463-3478 
Luo, Z. X., Shi, K., Li, W. D., \& Miao, D. M. (2008). Construct of Job Performance: evidence from Chinese military soldiers. Asian Journal of Social Psychology (11), 222-231.

Macey W, Schneider B. (2008). The meaning of employee engagement. Industrial and Organizational Psychology, $1,3-30$.

Macky, K. \& Boxall, P. (2007). The relationship between high performance work practices and employee attitudes: An investigation of additive and interaction effects. International Journal of Human Resource Management, $18,537-567$.

Motowidlo, S. J., \& Schmit, M. J. (1999). Performance Assessment in Unique Jobs. In D. R. Ilegen, \& E. D. Pulakos. The Changing Nature of Performance. San Francisco: JosseyBass, 56-86

Motowidlo, S. J., \& Van Scotter, J. R. (1994). Evidence that Task Performance Should be distinguished from Contextual Performance. Journal of Applied Psychology, 79(4), 475-480.

Newman, D. A., \& Harrison, D. A. (2008). Been there, bottled that: Are state and behavioral work engagement new and useful construct "wines"? Industrial and Organizational Psychology, 1: 31-35.

Park, Y. K., Song, J. H., Song, S. W. \& Kim, J. (2014). Learning Organization and innovative behavior: The mediating effect of work engagement. European Journal of Training and Development, 38(1/2), 75-94.

Podsakoff, P.M., MacKenzie, S.B., Lee, J. \& Podsakoff, N.P. (2003). Common Method Biases in Behavioral Research: A Critical Review of the Literature and Recommended Remedies. Journal of Applied Psychology, 88, (5): 879-903

Rich, B. L., LePine, J.A. \& Crawford, E.R. (2010). Job Engagement: Antecedents and Effects on Job Performance. Academy of Management Journal, 53(3): 617-635.

Saunders, M., Lewis, P. \& Thornhill, A. (2009). Research Methods for Business Students. $5^{\text {th }}$ Edition, Pearson Education Limited, Edinburgh, England

Schaufeli WB, Salanova M, Gonzalez-Roma V, Bakker AB. (2002). The measurement of engagement and burnout: A two sample confirmatory factor analytic approach. Journal of Happiness Studies, 3: 71-92.

Wallace, J., Butts, M., Johnson, P., Stevens, F., \& Smith, M. (2013). A multilevel model of employee innovation understanding the effects of regulatory focus, thriving, and employee involvement climate. Journal of Management, 1-23.

Welbourne, T. M., Johnson, D. E., \& Erez, A. (1998). The role-based performance scale: validity analysis of a theory-based measure. Academy of Management Journal, 41(5), 540-555.

Wright, P.M., \& Nishii, L. (2004). Strategic HRM and Organizational Behaviour: Integrating Multiple Level Analysis, Paper presented at the 'What Next for HRM' Conference, Rotterdam.

Zhang, Y., \& Li, S. (2009). High Performance Work Practices and Firm Performance: Evidence from the Pharmaceutical Industry in China. The International Journal of Human Resource Management, 20(11): $2331-2348$ 